\title{
Growth Response of Robusta Coffee (Coffea canephora L.) Seedlings to Exogenous Salicylic Acid Application
}

\author{
Novie Pranata Erdiansyah ${ }^{1 *}$ and Fakhrusy Zakariyya ${ }^{1)}$ \\ ${ }^{1)}$ Indonesian Coffee and Cocoa Research Institute, Jl. PB. Sudirman 90, Jember, Indonesia \\ ${ }^{*}$ Corresponding author: noviepranata@gmail.com \\ Received: 29 November 2021 / Accepted: 09 December 2021
}

\begin{abstract}
To accelerate growth performance of Robusta coffee (Coffea canephora) seedling could be conducted through the application of exogenous plant hormone. Salicylic acid is one of plant hormones that widely applied to increase the plant growth for several plants, however, for coffee was still relative limited. This study was aimed to determine the effect of salicylic acid on the growth of Robusta coffee seedlings which research was conducted at Indonesian Coffee and Cocoa Research Institute (ICCRI), Jember, East Java. This experiment was set using split plot design with three replications. The main plot was clones, which were BP 308 and Sintaro clones. The seedlings were propagated from rooted cuttings. The subplot was the concentration of exogenous salicylic acid, that were control, $0.6 \mathrm{mM}, 1.2 \mathrm{mM}$, and $1.8 \mathrm{mM}$. The result demonstrated that BP 308 clone had higher rooting performance than Sintaro clone that shown by the higher root volume, root dry mass, and root/shoot ratio. In general, the application of salicylic acid could enhance the growth of Robusta coffee seedling. The application of $0.6 \mathrm{mM}$ salicylic acid increased plant growth of coffee seedlings. There was different response to concentration of application salicylic acid for both clones. The application of $0.6 \mathrm{mM}$ salicylic acid could increase plant growth of BP 308, include plant height, leaf area, stem dry mass, leaf dry mass, root/shoot ratio and total dry mass. Meanwhile, on Sintaro clone, application of $1.2 \mathrm{mM}$ salicylic acid could increase leaf area, stem, leaf and total dry mass. The application of salicylic acid more than $1.2 \mathrm{mM}$ led to detrimental effect of coffee seedlings.
\end{abstract}

Keyword: $\quad$ salicylic acid, concentration, clones, seedlings, Coffea canephora L.

\section{INTRODUCTION}

Coffee is currently a trend for beverage for various segments of society. The consumption of coffee increased in the last decade which needs to be balanced with an increase in coffee production. Currently, coffee production in Indonesia is 685 thousand tonnes per year and has the potential to be increased (Ditjenbun, 2020). Increased coffee production needs to be supported by improving the quality of planting materials.
Increasing of the quality coffee planting materials could be conducted through the use of superior planting materials and implementation of good nursery practices. The using of clonal planting material through the propagation of rooted cuttings is currently common in Indonesia. BP 308 is the clone that considered to be a rootstock for coffee seedlings due to its superior rooting performance, meanwhile, Sintaro clone is superior planting materials for Robusta coffee which have high yield potential, resistant to pests 
and diseases, beside have good flavor. Moreover, BP 308 is a clone that has resistance to nematodes and drought (Sumirat et al., 2013).

The use of stimulants in improving plant quality is currently a consideration in nursery management and crop production. One of the stimulants that can be used to increase plant production is salicylic acid. Kumaraswamy et al. (2019) explained that salicylic acid added with chitosan nanoparticles is a sustainable stimulant compound. Salicylic acid is a naturally occurring phenolic compound in plants and vital component in the signal transduction pathway for the commencement of systemic acquired resistance (SAR). Salicylic acid can improve the growth and quality of plant seedlings. In addition, exogenous salicylic acid could affect plant growth, photosynthesis, water-plant relations, and the activity of several types of enzymes that play an important role in biotic and abiotic stresses (Zamaninejad et al., 2013). The role of salicylic acid as signal transduction in plant defense mechanism to the biotic and abiotic stress has been observed and characterized through some mechanisms. The mechanisms consist of conjugation, accumulation, and crosstalk of plant hormones such as jasmonic acid, ethylene, abscisic acid, auxin, gibberellin, cytokinin, and bras-sinosteroid (An \& Mou, 2011).

In coffee plants, salicylic acid has been investigated for accelerated germination of Arabica coffee (Gordillo Curiel et al., 2020), induction resistance of Arabica coffee to Colletotrichum kahawae Waller \& Bridge disease (Alemu et al., 2018) and leaf blight (Tannuri et al., 2021). However, research for Robusta coffee is still limited. This study aims to determine the effect of salicylic acid on the growth of Robusta coffee seedlings.

\section{MATERIALS AND METHODS}

The research was conducted at Indonesian Coffee and Cocoa Research Institute (ICCRI), Jember, East Java. The seedlings derived from rooted cuttings. This experiment was set using split plot design with three replications. The main plot was clone, which consisted of BP 308 and Sintaro clones. BP 308 was used in this trial since this clone was widely used as a rootstock for coffee grafting seedlings, meanwhile Sintaro was superior clone that high production. The subplot was the concentration of exogenous salicylic acid, that were control, $0.6 \mathrm{mM}, 1.2 \mathrm{mM}$, and $1.8 \mathrm{mM}$. The salicylic acid was applied three months after cutting process by soil drenching of $500 \mathrm{~mL}$ solution every two weeks.

Cutting process of coffee was conducted through two stages, which were rooting induction and transplanting to the polybag. Rooting induction stage was conducted in nursery raised bed. The media used top soil:sand:manure with the ratio of $1: 1: 1$. The mixture of top soil and manure was put in first layer (around 15-20 cm) the shifted sand in to top layer. The raised bed was covered with the plastic. To avoid the fungus attack, the closed raised bed was sprayed with the fungicide. Coffee budwoods were obtained from certified budwood garden of ICCRI in Kaliwining Experimental Station. Two until three segments of budwood was cut and dipped in to BAP (benzyl amino purine) $0.057 \%$ for $10-15$ minutes with the dosage $1.5-2 \mathrm{ml} \cdot \mathrm{L}^{-1}$. The plant spacing for cuttings was $10 \mathrm{~cm} \times 5 \mathrm{~cm}$. The maintenance activities were watering with the frequency once per day, weeding management, and pesticide spraying. After 3 months, seedlings derived from cutting was transplanted to the polybags with the top soil : manure media (1:1 ratio). 
Parameter observed were plant height, stem diameter, number of leaves, leaf thickness, leaf area, root volume, and plant dry mass. Plant height was observed by using ruler at 2 months after treatment (MAT) and 4 MAT. Stem diameter was observed by using caliper at 2 and 4 MAT. Leaf thickness, leaf area, root volume and plant dry mass was observed destructively at 4 MAT. Leaf thickness was measured by using caliper. Root volume was observed by using cylinder glass based on the increment of water level. Leaf area was assessed based on image analysis using Adobe Photoshop CS Software.

Data were analyzed using ANOVA with SAS software. If there is a significant difference, it will be continued with post hoc test Duncan multiple range test (DMRT) at $\alpha=5 \%$ level. For the analysis of disease incidence and severity data, it differentiated between control and treatments, then analyzed using post hoc test DMRT at $\alpha=$ $5 \%$ level.

\section{RESULTS AND DISCUSSION}

Coffee seedling growth stage consisted of two stages, 2 MAT as an early growth stage and 4 MAT as a standard of coffee seedling ready to be transplanted to the field. The summary of analysis of the result was presented in Table 1 which that at 2 MAT, plant height of the clones were affected, however, the salicylic acid was affected on stem diameter. At the end of observation the interaction between clone and salicylic treatment affected stem diameter and total dry mass. According to single factor of experiment, the salicylic acid affected plant height, leaf area, leaf thickness, leaf dry mass, stem dry mass, and root/shoot ratio, while, the clone affected stem diameter, leaf area, root volume, leaf dry mass, root dry mass, and root/shoot ratio.

Based on Table 2, plant height at 2 and 4 MAT was affected by clone and application of salicylic acid, respectively. BP 308

Table 1. Calculated $\mathrm{F}$ of the analysis of variance of plant height, stem diameter, number of leaves, leaf area, leaf thickness, root volume, leaf dry mass, stem dry mass, root dry mass, total dry mass, root/shoot ratio as affected by salicylic acid concentration and clones and their interaction

\begin{tabular}{lccc}
\hline Variables & SA concentration & Clones & Interaction \\
\hline Plant height (2 MAT) & $2.69 \mathrm{~ns}$ & $94.94 * *$ & $1.17 \mathrm{~ns}$ \\
Plant height (4 MAT) & $3.39 *$ & $4.70 \mathrm{~ns}$ & $2.59 \mathrm{~ns}$ \\
Stem diameter (2 MAT) & $4.00 *$ & $1.12 \mathrm{~ns}$ & $1.66 \mathrm{~ns}$ \\
Stem diameter (4 MAT) & $19.15 * *$ & $6.98 *$ & $4.68 *$ \\
Number of leaves (2 MAT) & $2.85 \mathrm{~ns}$ & $1.14 \mathrm{~ns}$ & $0.21 \mathrm{~ns}$ \\
Number of leaves (4 MAT) & $0.74 \mathrm{~ns}$ & $3.52 \mathrm{~ns}$ & $1.04 \mathrm{~ns}$ \\
Leaf area & $5.57 * *$ & $14.37 * *$ & $0.83 \mathrm{~ns}$ \\
Leaf thickness & $5.40 * *$ & $30.27 * *$ & $2.73 \mathrm{~ns}$ \\
Root volume & $1.70 \mathrm{~ns}$ & $7.32 *$ & $0.88 \mathrm{~ns}$ \\
Leaf dry mass & $5.66 * *$ & $13.79 * *$ & $2.39 \mathrm{~ns}$ \\
Stem dry mass & $4.43 *$ & $0.09 \mathrm{~ns}$ & $1.64 \mathrm{~ns}$ \\
Root dry mass & $2.11 \mathrm{~ns}$ & $10.81 *$ & $1.15 \mathrm{~ns}$ \\
Total dry mass & $1.66 \mathrm{~ns}$ & $4.87 \mathrm{~ns}$ & $4.32 *$ \\
Root/shoot ratio & $10.80 * *$ & $53.72 * *$ & $0.70 \mathrm{~ns}$ \\
\hline Notes:
\end{tabular}

Notes: $\mathrm{ns}=$ non significant difference; $*$ and $* *$ : significant at 1 and $5 \%$ probability levels, respectively. 
clones showed taller than Sintaro clone at first stage of growth 2 MAT, however at 4 MAT, there was no differences between both. Exogenous salicylic acid increased the height of Robusta coffee seedling at 4 MAT. The tallest seedling $(44.5 \mathrm{~cm})$ was recorded in this research where the coffee cuttings were drenched with 0.6 and $1.2 \mathrm{mM}$ of salicylic acid. This finding was similar with Sadhegipour \& Aghaei (2012) and Khan et al. (2020) that salicylic acid application increased plant height. Pasternak et al. (2019) reported that SA regulates IAA biosynthesis and transport by changing the Arabidopsis growth.
However, the increase of salicylic acid concentration beyond $1.8 \mathrm{mM}$ had detrimental effect on the plant height of Robusta coffee seedlings. Figure 1 demonstrated that the concentration of salicylic acid had quadratic equation, which had the optimum value. The optimum value of application of salicylic acid was $1.11 \mathrm{mM}$. This might be caused by toxicity level of salicylic acid on coffee seedling. Hussein et al. (2012) reported that $400 \mathrm{ppm}$ (equals to $2.89 \mathrm{mM}$ ) could decrease plant height.

Data regarding stem diameter was presented in Table 3 and Table 4. The application of salicylic acid affected stem diameter on both

Table 2. Effect of salicylic acid on the height of seedlings of two clones of C. canephora

\begin{tabular}{lcc}
\hline \multirow{2}{*}{ Treatments } & \multicolumn{2}{c}{ Plant height, cm } \\
\cline { 2 - 3 } & 2 MAT & 4 MAT \\
\hline BP 308 & $38.80 \mathrm{a}$ & $46.50 \mathrm{a}$ \\
Sintaro & $27.06 \mathrm{~b}$ & $39.70 \mathrm{a}$ \\
Salicylic acid concentration (mM) & & $40.50 \mathrm{p}$ \\
0 & $30.30 \mathrm{p}$ & $44.50 \mathrm{q}$ \\
0.6 & $34.75 \mathrm{p}$ & $44.00 \mathrm{pq}$ \\
1.2 & $33.91 \mathrm{p}$ & $43.40 \mathrm{pq}$ \\
\hline
\end{tabular}

Note : Data in the same column followed by the same letters were not significantly different according to the DMRT $5 \%$.

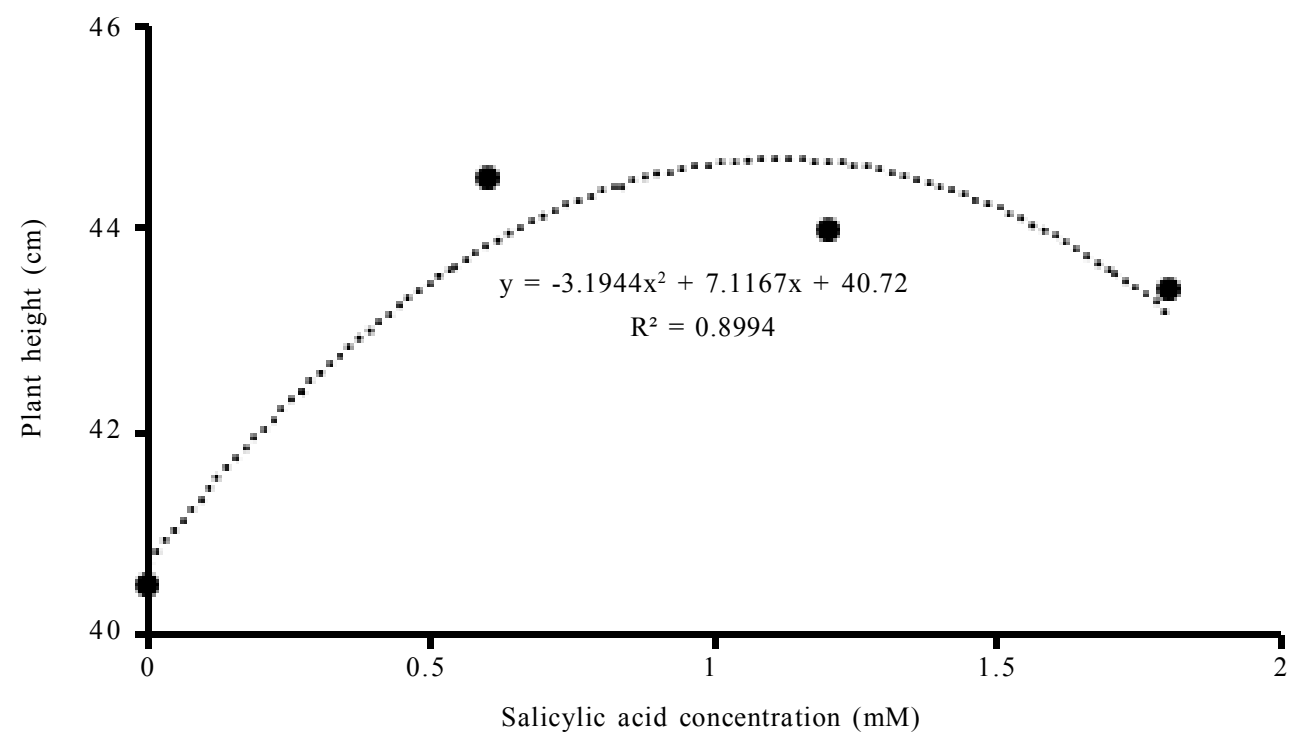

Figure 1. Relationship between salicylic acid concentration and plant height of coffee seedlings of both clones at 4 MAT 
clones after 2 months. The addition of $1.2 \mathrm{mM}$ salicylic acid could increase to $19.2 \%$ of stem diameter than control. At 4 MAT, there was an interaction between clone and salicylic acid concentration on stem diameter of coffee seedlings. BP 308 clone was more responsive to the increase of salicylic acid application than Sintaro clones. The addition of $0.6 \mathrm{mM}$ and $1.2 \mathrm{mM}$ salicylic acid could increase up to $26.5 \%$ of stem diameter of BP 308 clone coffee seedling. However, the increase of salicylic acid concentration did not significantly affect the stem diameter of Sintaro clone coffee seedling. Figure 2 demonstrated the quadratic trendline for stem diameter was also the same patterns with Figure 1. According to the quadratic equation, the optimum concentration of application salicylic acid concentration for BP 308 and Sintaro clones were $0.95 \mathrm{mM}$ and $1.08 \mathrm{mM}$, respectively.

Table 3. Effect of salicylic acid to stem diameter of two clones of C. canephora seedling at 2 MAT

\begin{tabular}{lc}
\hline Treatments & Stem diameter $(\mathrm{mm})$ \\
\hline BP 308 & $3.46 \mathrm{a}$ \\
Sintaro & $3.29 \mathrm{a}$ \\
Salicylic acid concentration $(\mathrm{mM})$ & \\
0 & $2.98 \mathrm{q}$ \\
0.6 & $3.54 \mathrm{pq}$ \\
1.2 & $3.68 \mathrm{p}$ \\
1.8 & $3.29 \mathrm{pq}$ \\
\hline Note: $\quad$ Data in the same column followed by the same letters were not significantly different according to the DMRT $5 \%$.
\end{tabular}

Table 4. Effect of salicylic acid to stem diameter $(\mathrm{mm})$ of two clones of C. canephora seedling at 4 MAT

\begin{tabular}{lcccc}
\hline \multirow{2}{*}{ Clones } & \multicolumn{4}{c}{ Salicylic acid concentration $(\mathrm{mM})$} \\
\cline { 2 - 5 } & 0 & 0.6 & 1.2 & 1.8 \\
\hline BP 308 & $3.94 \mathrm{c}$ & $5.36 \mathrm{a}$ & $5.04 \mathrm{ab}$ & $4.38 \mathrm{bc}$ \\
Sintaro & $3.94 \mathrm{c}$ & $4.48 \mathrm{bc}$ & $4.4 \mathrm{bc}$ & $4.3 \mathrm{bc}$ \\
\hline
\end{tabular}

Note: Data in the column and row followed by the same letters were not significantly different according to the DMRT $5 \%$.



Figure 2. Relationship between salicylic acid concentration and stem diameter of coffee seedling at 4 MAT 
According to Table 5, clones affected the leaf thickness, leaf area, and root volume at 4 MAT. Coffee seedlings of BP 308 clone had $26.6 \%$ higher of root volume, but lower of leaf thickness and leaf area than Sintaro clone. This result was supported with Sumirat et al. (2013) study who stated that BP 308 was coffee clone which is easy to emerge the root, had high number of primary root and long of primary root. Firdaus et al. (2021) reported that BP 308 clones led to emerge superior rooting system.

The application of exogenous salicylic acid increased the leaf thickness and leaf area. The higher concentration of salicylic acid, the thicker and wider of leaf. Leaf thickness was a trait that useful for the drought resistant of plant (Zakariyya et al., 2019).
Yeganehpoor et al. (2016) demonstrated that the addition of salicylic acid on coriander plant under drought stress and normal condition could increase the leaf area. However, the application of salicylic acid did not affect the root volume.

Table 6 showed that dry mass partition was affected by single factor of clones and salicylic acid concentration. However, there was an interaction between clone and salicylic acid concentration on total dry mass (Table 7). Clones affected the root dry mass, leaf dry mass, and root/shoot ratio. BP 308 had higher value of root dry mass and root/shoot ratio but had lower value of leaf dry mass than Sintaro. Application of salicylic acid affected the stem and leaf dry mass and decreased the root/shoot ratio. The concentration of $0.6 \mathrm{mM}$

Table 5. Effect of salicylic acid to leaf thickness (mm), number of leaf, leaf area $\left(\mathrm{cm}^{2}\right)$, and root volume $\left(\mathrm{cm}^{3}\right)$ per seedling of two clones of $C$. canephora at 4 MAT

\begin{tabular}{lcccc}
\hline Treatments & Leaf thickness, $\mathrm{mm}$ & Number of leaf & Leaf area, $\mathrm{cm}^{2}$ & Root volume, $\mathrm{cm}^{3}$ \\
\hline BP 308 & $0.60 \mathrm{~b}$ & $17.20 \mathrm{a}$ & $1087.85 \mathrm{~b}$ & $28.25 \mathrm{a}$ \\
Sintaro & $1.14 \mathrm{a}$ & $18.60 \mathrm{a}$ & $1352.55 \mathrm{a}$ & $20.75 \mathrm{~b}$ \\
Salicylic acid concentration (nM) & & & & \\
0 & $0.63 \mathrm{q}$ & $18.30 \mathrm{p}$ & $929.19 \mathrm{q}$ & $24.00 \mathrm{p}$ \\
0.6 & $0.98 \mathrm{p}$ & $18.30 \mathrm{p}$ & $1168.96 \mathrm{pq}$ & $26.00 \mathrm{p}$ \\
1.2 & $0.97 \mathrm{p}$ & $17.90 \mathrm{p}$ & $1456.83 \mathrm{p}$ & $27.50 \mathrm{p}$ \\
1.8 & $0.89 \mathrm{pq}$ & $17.10 \mathrm{p}$ & $1325.82 \mathrm{p}$ & $20.50 \mathrm{p}$ \\
\hline Note: $\quad$ Data in the same column followed by the same letters were not significantly different according to the DMRT $5 \%$.
\end{tabular}

Table 6. Root dry mass, stem dry mass, leaf dry mass, and root/shoot ratio of two clones of $C$. canephora seedling at 4 MAT

\begin{tabular}{lcccc}
\hline Clones & Root dry mass, g & Stem dry mass, $\mathrm{g}$ & Leaf dry mass, g & Root/Shoot ratio \\
\hline BP 308 & $6.63 \mathrm{a}$ & $5.04 \mathrm{a}$ & $5.61 \mathrm{~b}$ & $0.63 \mathrm{a}$ \\
Sintaro & $4.81 \mathrm{~b}$ & $5.19 \mathrm{a}$ & $7.20 \mathrm{a}$ & $0.42 \mathrm{~b}$ \\
Salicylic acid concentration $(\mathrm{nM})$ & & & \\
0 & $6.24 \mathrm{p}$ & $3.92 \mathrm{p}$ & $5.01 \mathrm{q}$ & $0.69 \mathrm{p}$ \\
0.6 & $5.76 \mathrm{p}$ & $5.60 \mathrm{q}$ & $6.55 \mathrm{pq}$ & $0.50 \mathrm{q}$ \\
1.2 & $6.02 \mathrm{p}$ & $5.93 \mathrm{q}$ & $7.00 \mathrm{p}$ & $0.48 \mathrm{q}$ \\
1.8 & $4.86 \mathrm{p}$ & $5.01 \mathrm{pq}$ & $7.08 \mathrm{p}$ & $0.43 \mathrm{q}$ \\
\hline Note: $\quad$ Data in the same column followed by the same letters are not significantly different according to the DMRT $5 \%$.
\end{tabular}

Table 7. Effect of salicylic acid on total dry mass (g) per seedling of two clones of C. canephora seedling at 4 MAT

\begin{tabular}{lcccc}
\hline \multirow{2}{*}{ Clones } & \multicolumn{4}{c}{ Salicylic acid concentration (mM) } \\
\cline { 2 - 5 } & 0 & 0.6 & 1.2 & 1.8 \\
\hline BP 308 & $20.80 \mathrm{~b}$ & $22.00 \mathrm{a}$ & $18.01 \mathrm{bc}$ & $15.32 \mathrm{~cd}$ \\
Sintaro & $12.66 \mathrm{~d}$ & $16.69 \mathrm{bcd}$ & $18.51 \mathrm{bc}$ & $17.00 \mathrm{bcd}$ \\
\hline Note: $\quad$ Data in the column and row followed by the same letters are not significantly different according to the DMRT $5 \%$.
\end{tabular}


to $1.2 \mathrm{mM}$ could increase the leaf dry mass and root/shoot ratio. According to Table 7 application of $1.2 \mathrm{mM}$ salicylic acid could increase total dry mass on Sintaro clone, while, in BP 308 clones, application of $0.6 \mathrm{mM}$ salicylic acid increased dry mass. Based on the parabolic equation (Figure 3), the optimum concentration of salicylic acid for Sintaro clones was $1.21 \mathrm{mM}$. However, the increase of salicylic acid concentration more than $1.5 \mathrm{mM}$ could decrease the total dry mass on both clones. This report was in lined with Gorni et al. (2017) study in fennel that the exogenous application of salicylic acid increased the plant shoot dry mass.

Based on the results above, application of salicylic acid affected the plant growth and biomass of Robusta coffee seedling. In general, exogenous salicylic acid application through drenching method increase the shoot growth and development in coffee seedling. This study showed that application of salicylic acid had much higher effects on shoot than on root characteristics and it was in lined with the study in muskmelon seedling by Korkmaz et al. (2007). It was contrary with Dehnavi et al. (2019) study in sorghum plant that root dry mass was more affected by exogenous salicylic acid than shoot dry mass. In other hand, other studies that reported application of salicylic acid could increase plant growth as presented for pea (Oliveira et al., 2020), fennel (Gorni et al., 2017), potato (Alhoshan et al., 2019), and Eucalyptus spp. (de Souza Junior et al., 2021).

The mechanism of salicylic acid to improve the plant growth had been discussed by several researches (Rivas-San Vicente \& Placentia, 2011; Dempsey \& Klessig, 2017; Koo et al., 2020). Plant commonly synthesized this compound endogenously, but MaruriLopez et al. (2019) stated that endogenous salicylic acid increased in lined with application of exogenous salicylic acid. Salicylic acid plays role in physiological and biochemical process in plant, especially in affecting other plant hormone. Salicylic acid had a synergetic effect on auxin and gibberellin

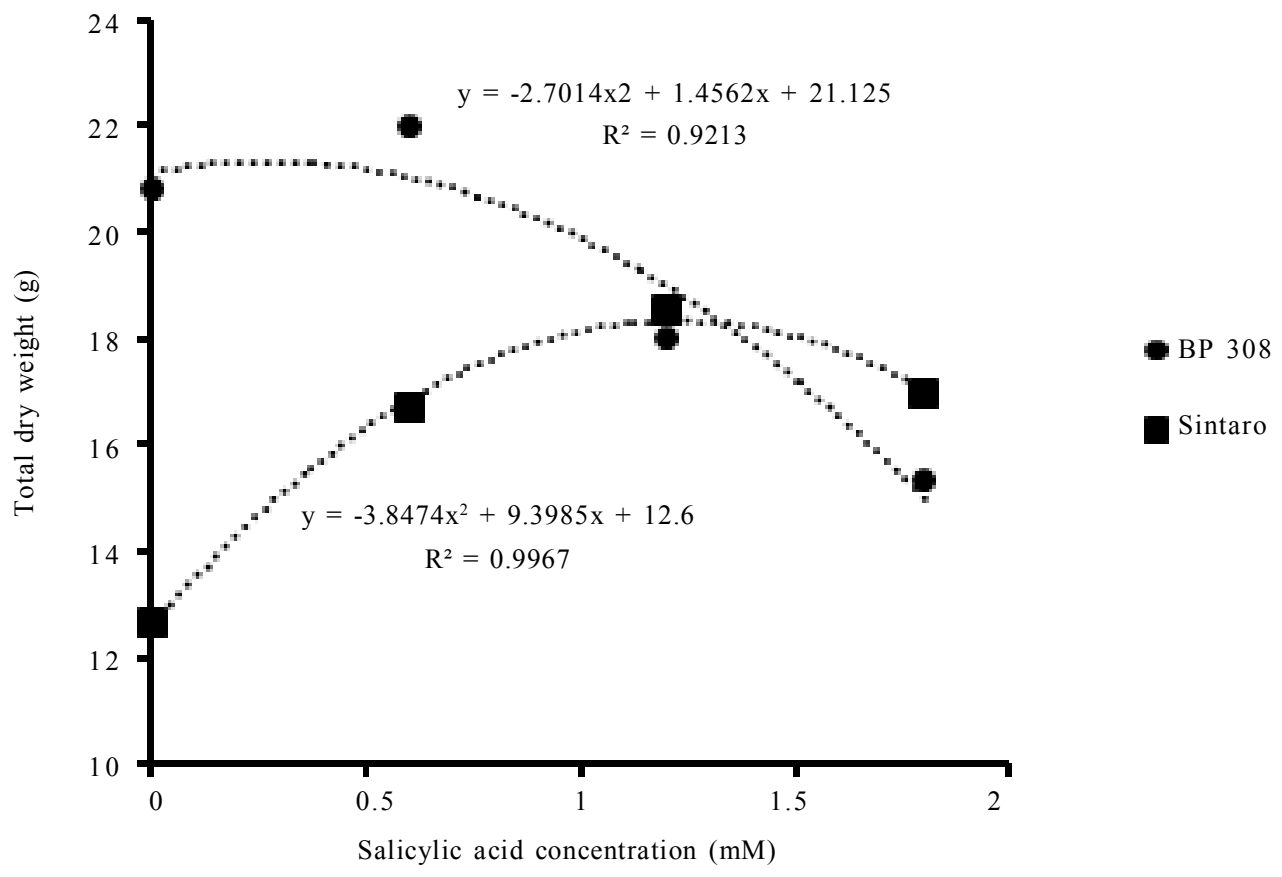

Figure 3. Relationship between salicylic acid concentration and total dry weight of coffee seedling at 4 MAT 
which were growth promoters responsible for the growth and developments of plant (Rivas-San Vicente \& Plasencia, 2011). Auxin is synthesized in the meristem of the plant which is responsible for plant height, while their function is regulated by salicylic acid.

Exogenous salicylic acid application could increase physiological aspects, i.e. increase photosynthetic process (Ahanger et al., 2020), stimulation of antioxidant system (El-Hady et al., 2021), protecting cell membranes against oxidative stress through adjusting osmolyte metabolism (Moustafa-Farag et al., 2020), stomatal movement (Zakariyya et al., 2018) and enhancing nutrient absorption (Gorni et al., 2020). High levels of salicylic acid (around $>2 \mathrm{mM}$ considered as high concentration) had detrimental effect on plant growth. Sadhegipour \& Aghaei (2012) reported higher concentration of salicylic acid showed negative results while low to medium concentration significantly improve plant height, leaf area index and protein yield in common bean crop. Dempsey \& Klessig (2017) stated that salicylic acid ruled in regulating the status of cellular redox, which was in low concentrations induced low-level accumulation of reactive oxygen species, which served as secondary signals to activate biological processes. However, high concentrations of exogenous salicilic acid stimulate the accumulation of high levels of reactive oxygen, which cause cell death by oxidative stress.

\section{CONCLUSIONS}

The exogenous application of salicylic acid could promote Robusta coffee seedling growth. BP 308 clone had higher rooting performance than Sintaro clone that shown by the higher root volume, root dry mass, and root/shoot ratio. Generally, the optimum concentration of salicylic acid was $0.6 \mathrm{mM}$ that increased plant growth of coffee seedling. There was different response to concentration of salicylic acid application for both clones. The application of $0.6 \mathrm{mM}$ salicylic acid on BP 308 clone could increase plant growth, include plant height, leaf area, stem dry mass, leaf dry mass, root/shoot ratio and total dry mass. Meanwhile, for Sintaro clone, application of higher concentration up to $1.2 \mathrm{mM}$ could increase leaf area, stem, leaf and total dry mass. The application of salicylic acid more than $1.2 \mathrm{mM}$ led the detrimental effect of coffee seedling.

\section{ACKNOWLEDGEMENT}

The authors gratefully acknowledge $\mathrm{Mr}$. Gito Nugraha Budikesuma, Mr. Hikmatullah Adi Cahyo, and Mr. Herwanto that supported preparation and implementation of this study.

\section{REFERENCES}

Ahanger, M.A.; U. Aziz; A.A. Alsahli; M.N. Alyemeni \& P. Ahmad (2020). Influence of exogenous salicylic acid and nitric oxide on growth, photosynthesis, and ascorbate-glutathione cycle in salt stressed Vigna angularis. Biomolecules, 10(1), 42.

Alemu, K.; G. Adugna; F. Lemessa \& D. Muleta (2018). Induction of systemic resistance in Arabica coffee (Coffea arabica L.) against coffee berry disease (Colletotrichum kahawae Waller \& Bridge) mediated through plant defense activator. International Journal of Pest Management, 65(4), 313-323.

Alhoshan, M.; M. Zahedi; A.A. Ramin \& M.R. Sabzalian (2019). Exogenous application of salicylic acid and glycine betaine as tools to enhance biomass and tolerance of potato cultivars. Gesunde Pflanzen, 71(1), 25-35. 
An, C. \& Z. Mou (2011), Salicylic acid and its function in plant immunity. Journal of Integrative Plant Biology, 53, 412-428.

Dehnavi, A.R.; Z. Morteza; J. Razmjoo \& H. Eshghizadeh (2019). Effect of exogenous application of salicylic acid on saltstressed sorghum growth and nutrient contents. Journal of Plant Nutrition, 42, 11-12.

Dempsey, D.A. \& D.F. Klessig (2017). How does the multifaceted plant hormone salicylic acid combat disease in plants and are similar mechanisms utilized in humans?. BMC Biology, 15, 23.

de Souza Junior, J.P.; R.D.M. Prado; T.C.B. de Morais; J.J. Frazão; M.M. dos Santos Sarah; K.R. de Oliveira \& R.C. de Paula (2021). Silicon fertigation and salicylic acid foliar spraying mitigate ammonium deficiency and toxicity in Eucalyptus spp. clonal seedlings. Plos One, 16(4), e0250436.

Ditjenbun (2020). Statistik Perkebunan Indonesia: Komoditas Kopi. Direktorat Jenderal Perkebunan, Kementerian Pertanian. Jakarta, Indonesia.

El-Hady, N.A.A.A.; A.I. ElSayed; S.S. El-Saadany; P.A. Deligios \& L. Ledda (2021). Exogenous application of foliar salicylic acid and propolis enhances antioxidant defenses and growth parameters in tomato plants. Plants, 10(1), 74.

Firdaus, N.K.; D. Pranowo \& E. Wardiana (2021). Study of growing media composition and cuttings material in clonal seedlings production of Robusta coffee. Jurnal Tanaman Industri dan Penyegar, 8(2), 99-108.

Gordillo-Curiel, A.; L.A.R. Larramendi; M.A.S. Marina \& M.D.L.A.R. Esquinca (2020). Effect of salicylic acid on the germination and initial growth of coffee (Coffea arabica L. var. Costa Rica 95). Revista de la Facultad de Agronomia de la Universidad Del Zulia, 38(1), 43-59.
Gorni, P.H.; A.C. Pacheco; A.L. Moro; J.F.A. Silva; R.R. Moreli; G.R. de Miranda; J.M. Pelegrini; K.D. Spera; J.L.B. Junior \& R.M.G. da Silva (2020). Salicylic acid foliar application increases biomass, nutrient assimilation, primary metabolites and essential oil content in Achillea millefolium L. Scientia Horticulturae, 270, 109436.

Gorni, P.H.; M.D.O. Brozulato; R.D.S. Lourenção \& E.C.G. Konrad (2017). Increased biomass and salicylic acid elicitor activity in fennel (Foeniculum vulgare Miller). Brazilian Journal of Food Technology, 20.

Hussein, M.M.; H.M. Mehanna \& N. AbouBaker (2012). Growth, photosynthetic pigments and mineral status of cotton plants as affected by salicylic acid and salt stress. Journal of Applied Sciences Research, 8(11), 5476-5484.

Khan, A.; M. Kamran; M. Imran; A. Al-Harrasi; A. Al-Rawahi; I. Al-Amri; I.J. Lee \& A.L. Khan (2019). Silicon and salicylic acid confer high-pH stress tolerance in tomato seedlings. Scientific Reports, 9(1), 1-16.

Koo, Y.M.; A.Y. Heo \& H.W. Choi (2020). Salicylic acid as a safe plant protector and growth regulator. Plant Pathology Journal, 36(1), 1-10.

Korkmaz, A.; M. Uzunlu \& A.R. Demirkiran (2007). Treatment with acetyl salicylic acid protects muskmelon seedlings against drought stress. Acta Physiologiae Plantarum, 29(6), 503-508.

Kumaraswamy, R.V.; S. Kumari; R.C. Choudhary; S.S. Sharma; A. Pal; R. Raliya; P. Biswas \& V. Saharan (2019). Salicylic acid functionalized chitosan nanoparticle: A sustainable biostimulant for plant. International Journal of Biological Macromolecules, 123, 59-69.

Maruri-López I.; N.Y. Aviles-Baltazar; A. Buchala \& M. Serrano (2019). Intra and extracellular journey of the phytohormone salicylic acid. Frontier Plant Science, $10,423$. 
Moustafa-Farag, M.; H.I. Mohamed; A. Mahmoud; A. Elkelish; A.N. Misra; K.M. Guy; M. Kamran; S. Ai \& M. Zhang (2020). Salicylic acid stimulates antioxidant defense and osmolyte metabolism to alleviate oxidative stress in watermelons under excess boron. Plants, 9(6), 724.

Oliveira, K.R.; J.P.S. Junior; S.J. Bennett; M.V. Checchio; R. de Cássia Alves; G. Felisberto; R. de Mello Prado \& P.L. Gratão (2020). Exogenous silicon and salicylic acid applications improve tolerance to boron toxicity in field pea cultivars by intensifying antioxidant defence systems. Ecotoxicology and Environmental Safety, 201, 110778.

Pasternak T., E.P. Groot; F.V. Kazantsev; W. Teale; N. Omelyanchuk; V. Kovrizhnykh; K. Palme \& V.V. Mironova(2019). Salicylic acid affects root meristem patterning via auxin distribution in a concentration-dependent manner. Plant Physiology, 180, 1725-1739.

Rivas-San Vicente, M. \& J. Plasencia (2011). Salicylic acid beyond defence: its role in plant growth and development. Journal of Experimental Botany, 62(10), 3321-3338.

Sadeghipour, O. \& P. Aghaei (2012). Impact of exogenous salicylic acid application on some traits of common bean (Phaseolus vulgaris L.) under water stress conditions. International Journal of Agriculture and Crop Sciences, 4(11), 685-690.

Sumirat, U.; F. Yuliasmara \& Priyono (2013). Analisis sifat-sifat pertumbuhan setek pada kopi Robusta (Coffea canephora Pierre.). Pelita Perkebunan, 29(3), 159-173.
Tannuri, L.A.R.; E.A. Lopes; W.R. Macedo \& E.J. Canedo (2021). Exogenous application of salicylic acid to control coffee rust. Acta Scientiarum. Biological Sciences, 43, e54495-e54495.

Yeganehpoor, F.; S.Z. Salmasi; J.S. Kolvanagh; K.G. Golezani \& S. Dastborhan (2016). Changes in growth, chlorophyll content and grain yield of coriander (Coriandrum sativum L.) in response to water stress, chemical and biological fertilizers and salicylic acid. International Journal of Advanced Biological and Biomedical Research, 4(3), 229-237.

Zakariyya, F.; A.W. Susilo; T.I. Santoso; H.S. Addy \& S. Pancaningtyas (2018). Role of exogenous salicylic acid and benzoic acid applications to vascular streak dieback disease attack on cocoa seedlings. Pelita Perkebunan, 34(1), 33-39.

Zakariyya, F.; D, Indradewa \& T.I. Santoso (2019). Changes of leaf anatomical profile of cocoa clones seedlings in response to drought. Pelita Perkebunan, 35(3), 177-185.

Zamaninejad, M.; S.K. Khorasani; M.J. Moeini \& A.R. Heidarian (2013). Effect of salicylic acid on morphological characteristics, yield and yield components of corn (Zea mays L.) under drought condition. European Journal of Experimental Biology, 3(2), 153-161.

$* * 0 * *$ 